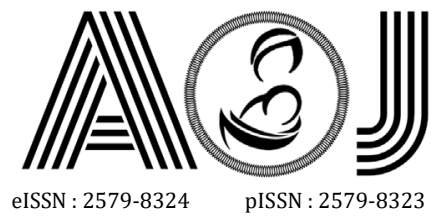

\title{
Clinical Appearance Of Tinea Corporis Resembles With Tinea Imbricata And Condyloma Acuminata Genital In A Reproductive Woman With HIV : A Case Report
}

\author{
Indah Kencana ${ }^{1}$, Tutty Ariani², Qaira Anum ${ }^{3}$, Yosse Rizal ${ }^{2}$ \\ Affiliation author: 1. Dermatology and Venereology Department, Faculty of Medicine, Andalas \\ University, Dr. M. Djamil Central General Hospital Padang, West Sumatera, Indonesia; 2. Infection \\ Division of Dermatology and Venereology Department, Faculty of Medicine, Andalas University, Dr. \\ M. Djamil Central General Hospital Padang, West Sumatera, Indonesia; 3. Sexually Transmitted \\ Infection Division of Dermatology and Venereology Department, Faculty of Medicine, Andalas \\ University, Dr. M. Djamil Central General Hospital Padang, West Sumatera, Indonesia
}

Correspondence to: Indah Kencana, email: indahkencana@gmail.com, Hp: 082285181791

\begin{abstract}
Background: HIV (human immunodeficiency virus) is a virus that attacks the body's immune system that can cause immunodeficiency. Immunodeficiency results in increased susceptibility to fungal infections. The other opportunistic infection, condyloma acuminate is prevalent in groups at high risk for HIV acquisition and in HIV-infected individuals.

Case: There were ring-shaped reddish patches with scaly and itchy on the right back since 3 weeks ago. Patients often scratch it especially when sweating and hot weather. The itchy reddish patches with scaly were increased in number and size on the right back then spreading over the edge to form ring-like patches. Patient complained ring-shaped reddish patches getting more red, scaly, itchy, and wider. 6 months ago, there was a lump that sometime felt itchy in below part of vulva. Patient in reproductive age and not married yet, but sexually active. Patient had a sexual relation with male who HIV 2 years ago. Patient also suffered HIV and got ARV since 6 month ago. There was no protection (condom) during the sexual intercourse. Dermatologic state in right back with efflorescence is plaque erythema with annular concentric ring forms, scale, and blackish crust. Venereologycal state show vegetation in vulva with size 0,2 - 1,5 $\times 1 \times 0,5 \mathrm{~cm}$ with verrucous surface. Acetowhite test is positive result. $\mathrm{KOH}$ $10 \%$ of skin scrapping show fungal element and fungal culture result is tricophyton rubrum. Patient was diagnosed tinea corporis (TC) and condyloma acuminata (CA) genital griseovulfin $900 \mathrm{mg}$, cetirizin $10 \mathrm{mg}$, ketokonazol $2 \%$ cream twice a day, tricholoroacetat $90 \%$ and showed good improvement.
\end{abstract}

Discussion: Diagnosis tinea corporis and CA genital based on clinical findings and mycological examination. Early diagnosis and proper treatment are important in HIV patients in order to prevent severe infection. After 4 weeks treatment, show improvement on TC however CA lesion no reduced.

Keywords: tinea corporis, condyloma acuminate, tinea imbricata, HIV, Reproductive age

Received : June $9^{\text {th }}, 2021$ 


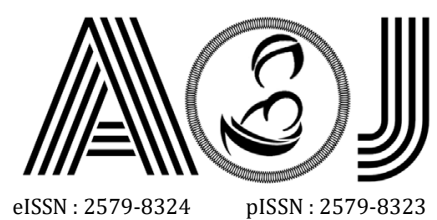

eISSN : 2579-8324
pISSN : 2579-8323

Editorial Room Andalas Obstetrics and Gynecology Journal, $3^{\text {rd }}$ floor of KSM of Obstetrics and Gynecology, RSUP DR. M. Djamil Padang, Jl. Perintis Kemerdekaan Padang, Sumatera Barat 25127

Website:

http://jurnalobgin.fk.unand.ac.id/index.php/JOE

\section{BACKGROUNDS}

HIV (human immunodeficiency virus) is a virus that attacks the body's immune system and weakens people's defense against many infections and some types of cancer. As the virus destroys and impairs the function of immune cells, infected individuals gradually become immunodeficient. Immune function is typically measured by CD4 cell count. Immunodeficiency results in increased susceptibility to a wide range of infections, cancers and other diseases that people with healthy immune systems can fight off. In HIV, a weakened immune system increases vulnerability to a number of opportunistic infections, cancers, and other conditions. Opportunistic infections (Ols) are defined as infections that are more frequent or more severe because of immune suppression in HIV-infected patients, and they are the major clinical manifestation of HIV patients. OI cause signifificant morbidity and mortality in people with HIV infection. The risk for the development of OI in HIV patients depends on exposure to potential pathogens, virulence of the pathogens, the degree of host immunity, and the use of antimicrobial prophylaxis. ${ }^{1,2,3}$

Tinea corporis is a superficial fungal skin infection of the body caused by dermatophytes. Tinea corporis is present worldwide. It is defined explicitly by the location of the lesions that may involve the trunk, neck, arms, and legs. Fungi are major contributors to the opportunistic infections that affect patients with HIV/AIDS. The incidence of dermatophytosis in HIV patients was about $15-40 \%{ }^{1,5,6,7}$

Another vulnerable population includes patients with compromised immune systems. Dermatophytes are a group of pathogenic fungi that cause mostly superficial diseases, further it is more difficult to diagnose dermatophytosis in immunocompromised patients, as clinical presentation is often atypical, in the present case multiples localization were recorded. Dermatophytes are the most prevalent agents of superficial fungal infections. The dermatophyte's ability to attach to the keratinized tissue of skin forms the basis for the dermatophytoses (superficial fungal skin infections. The dermatophytes causing tinea corporis belong to genera Trichophyton, Epidermophyton, and Microsporum. Trichophyton rubrum is the most common species to cause dermatophyte infections in the last 70 years. $T$. Rubrum accounts for 80 to $90 \%$ of the strains. Other common isolates include Trichophyton 


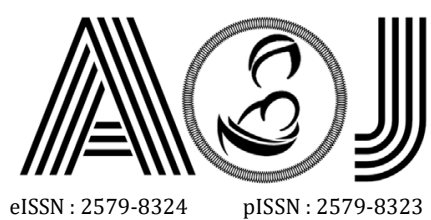

eISSN : 2579-8324
pISSN : 2579-8323

Editorial Room Andalas Obstetrics and Gynecology Journal, $3^{\text {rd }}$ floor of KSM of Obstetrics and Gynecology, RSUP DR. M. Djamil Padang, Jl. Perintis Kemerdekaan Padang, Sumatera Barat 25127

Website:

http://jurnalobgin.fk.unand.ac.id/index.php/JOE

mentagrophytes and Microsporum audouinii. HIV-positive patients is most commonly associated with T. rubrum, which is also the most common agent in skin fungal infections. ${ }^{4,6,7}$

The diagnosis of tinea corporis is usually clinically based on a thorough history and physical examination. However, testing can be done to confirm the diagnosis. Skin scrapings examined under a microscope with a potassium hydroxide $(\mathrm{KOH})$ preparation will reveal septate and branching long narrow hyphae. However, up to $15 \%$ of cases may yield false negatives when only using $\mathrm{KOH}$ preparations for diagnosis. ${ }^{9,10}$

Therefore another method for confirmation is a fungal culture. Fungal cultures are possible but take time for definitive identification. Cultures may begin to see growth in about five days but may take up to four weeks in certain species. Therefore at least four weeks are needed to deem a sample as "no growth." The most common isolation medium used for fungal cultures is a Sabourad dextrose agar (1\% glucose, $4 \%$ mycological peptone agar, water). Identification is by examining the morphology, pigmentation, and surface topography of the culture. $7,8,10$

Clinical manifestations of dermatophytosis associated with CD4 cell count of HIV patients in the study showed there are 3 in patients cases of tinea corporis with low CD4 counts $\left(<200\right.$ cells $\left./ \mathrm{mm}^{3}\right)$ and 1 case of tinea cruris with CD4 count of 200-350 cells / $\mathrm{mm}^{3}$. Skin disorders such as seborrheic dermatitis, candidiasis cutis and dermatophytosis are common in patients with a CD4 count of 400 cells $/ \mathrm{mm} 3$. Dermatophyte fungi cases was more found in patient with CD4 count $<200$ cells $/ \mathrm{mm} 3$. This shows that a decrease in the patient's immunological status has an effect on the increased likelihood of dermatophyte fungal infection, so that more clinical manifestations are found at low CD4 counts. ${ }^{1,2,5,9}$

HPV is highly infectious and is transmitted between persons via microabrasions during sexual skin-to-skin contact. Most initial HPV infections occur in adolescence, making early prevention critical. After initial HPV infection, patients may have clearance of subclinical infection, development of lesions with subsequent regression, persistence of infection with subsequent regression, or persistence of infection with development of cancer. Most HPV infections are subclinical and are cleared by the immune system via the cell-mediated immune response before any clinical disease is observed. Clinical CA genital may also undergo 


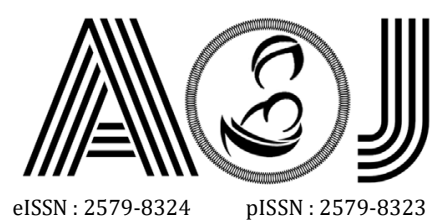

eISSN : 2579-8324
pISSN : 2579-8323

Editorial Room Andalas Obstetrics and Gynecology Journal, $3^{\text {rd }}$ floor of KSM of Obstetrics and Gynecology, RSUP DR. M. Djamil Padang, Jl. Perintis Kemerdekaan Padang, Sumatera Barat 25127

regression as a result of cell-mediated immunity. There is a significant increase in the number of HIV target cells in CA genital and provides evidence of enhanced HIV infection of CA genital in vitro. These findings suggest that CA genital may provide portals for HIV transmission and reinforce the importance of prevention and treatment of CA genital to control the HIV epidemic. $^{1,2,10,11,12}$

Oral systemic antifungal drugs effectively eradicate tinea corporis in immunocompromised hosts. Such agents include griseofulvin, ketoconazole, terbinafine, itraconazole, and fluconazole. Dermatophytosis in immunocompromised hosts is more varied and often more severe than in immunocompetent hosts. Early diagnosis and treatment with systemic therapy are important in human immunodeficiency virus (HIV) patients in order to prevent severe infection. ${ }^{1,8,15,16}$

\section{DISCUSSION}

A 33 years old woman was came to outpatient clinic of Dermato-Venereology Department of Dr. M. Djamil Hospital on March $26^{\text {th }} 2021$ with there were ring-shaped reddish patches with scaly and itchy which is expanding on the right back. There was a history bathing and changing clothes 1 times a day. Her sister also complaint the reddish patches on bottom since 1 month ago and never treated. There was a history bathing and changing clothes 1 times a day. About 6 months ago, there was a lump that sometime felt itchy in below part of vulva. Patient was never treating the lump until the lump increased in size and number in vulva. Patient never gets married before but, she had a sexual relation with married male. The last sexual intercourse was 2 years ago, genito-genitally, oro-genitally and ano-genitally. There was no protection (condom) during the sexual intercourse. Patient partner was died with HIV about 1 year ago. 6 months ago, patient complaint shortness of breath and admitted in Pulmonology Department with CAP (community acquired pneumonia). Then performed a laboratory examination and obtained an HIV positive. Patient was diagnosed with HIV and regularly taking ARVs drug; Tenolam E once a day. 


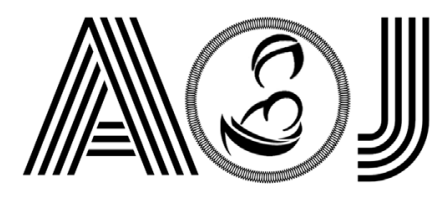

eISSN : 2579-8324
pISSN : 2579-8323

Editorial Room Andalas Obstetrics and Gynecology Journal, $3^{\text {rd }}$ floor of KSM of Obstetrics and Gynecology,
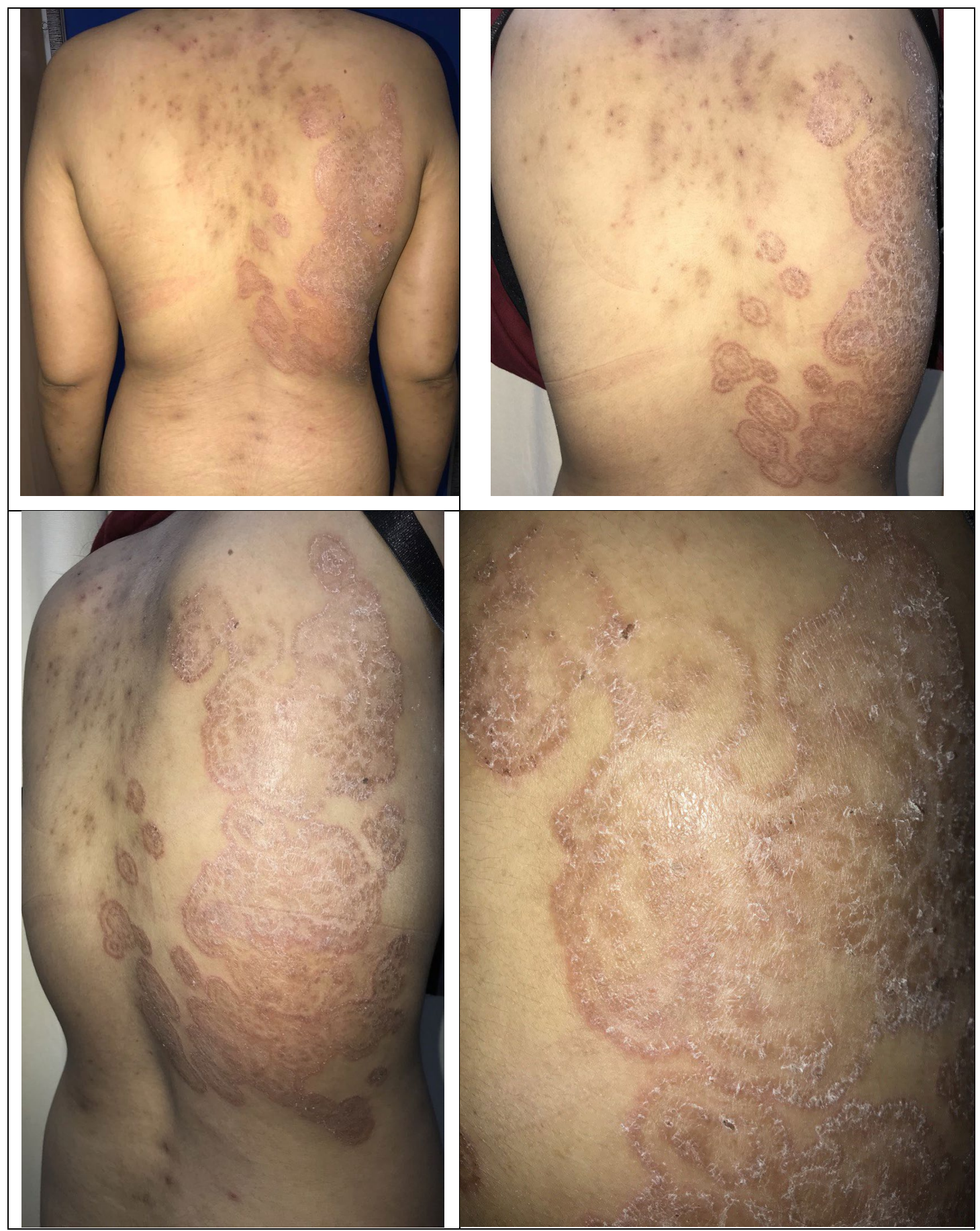

Figure 1. The patient's lesion on the right back shows plaque erythema with annular concentric ring forms, scale, and blackish crust.

Acetowhite test is positive result. CD4 70 (404-1612) se/ul, CD8 : $10 \quad(33-58) \%$, Rasio CD4: CD8 : 0,03 (Normal 0,69-2,83).

Received : June $9^{\text {th }}, 2021$

Accepted : June 19 $9^{\text {th }}, 2021$

Correspondence : Indah Kencana, email: indahkencana@gmail.com 


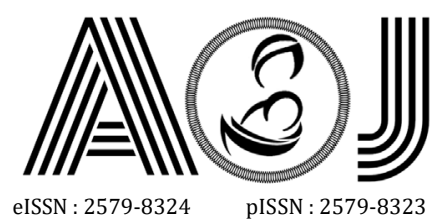

eISSN : 2579-8324

Editorial Room Andalas Obstetrics and Gynecology Journal, $3^{\text {rd }}$ floor of KSM of Obstetrics and Gynecology, RSUP DR. M. Djamil Padang, Jl. Perintis Kemerdekaan Padang, Sumatera Barat 25127

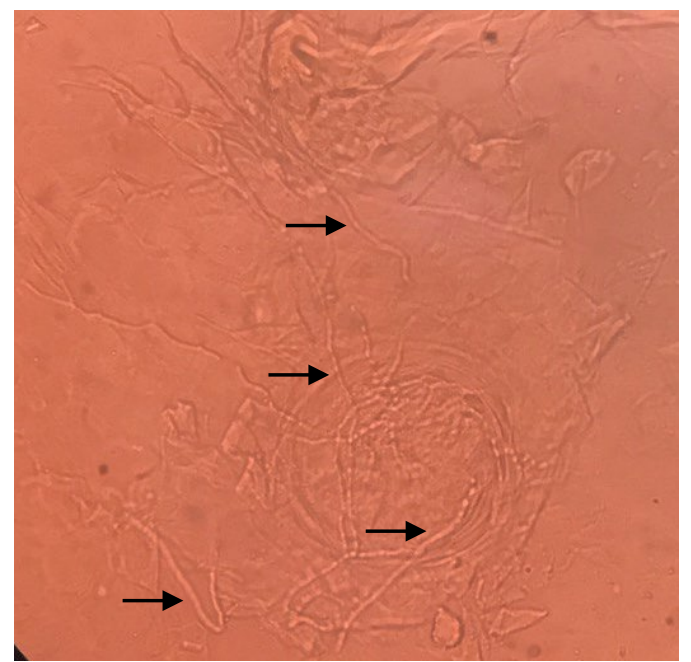

Figure 2. $\mathrm{KOH} 10 \%$ Examination of skin scrapping. The results of $\mathrm{KOH} 10 \%$ examination of skin scrapping revealed hypha with septum (black arrows).

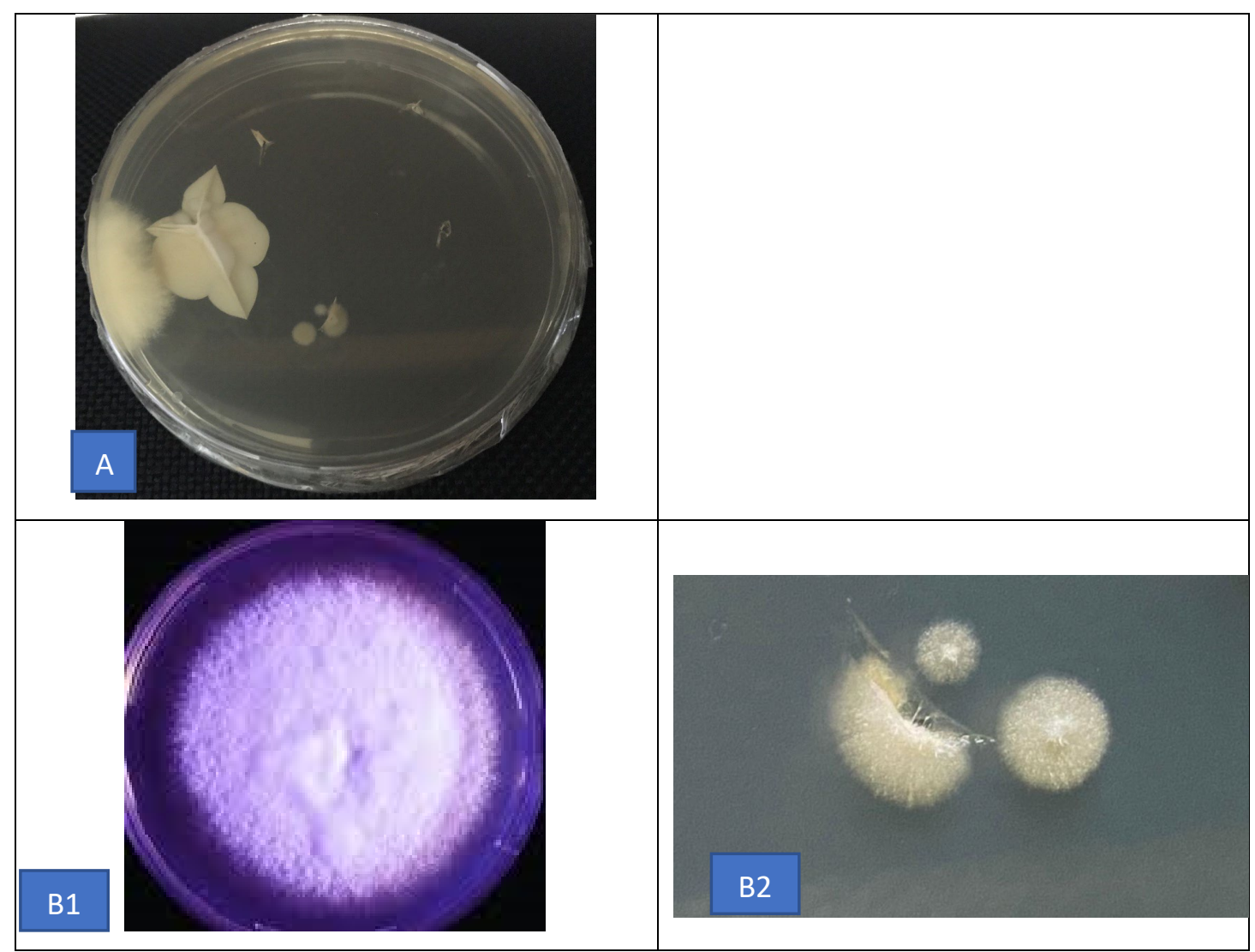

Received : June $9^{\text {th }}, 2021$ 
eISSN : $2579-8324$

Editorial Room Andalas Obstetrics and Gynecology Journal, $3^{\text {rd }}$ floor of KSM of Obstetrics and Gynecology, RSUP DR. M. Djamil Padang, Jl. Perintis Kemerdekaan Padang, Sumatera Barat 25127

\section{Website:}

http://jurnalobgin.fk.unand.ac.id/index.php/JOE

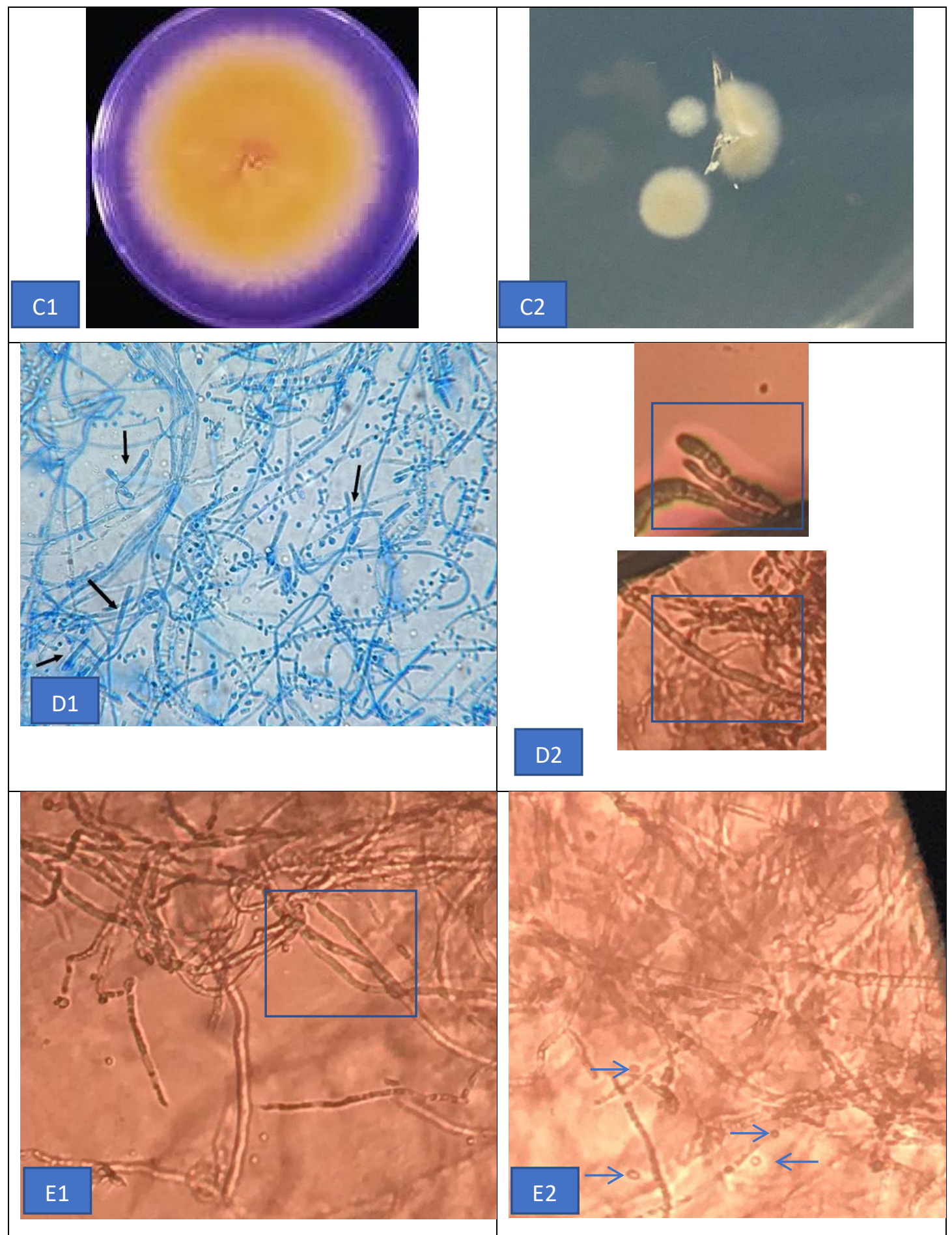

Figure 3. $\mathrm{A}$ is patient colony at $20^{\text {th }}$ days of culture with Sabaroud Agar. B1, C1, D1 are colony and microscopic morphology features from literature. D1 show tear-shaped micronidia and pencilshaped macroconidia From patient's microscopic appearance show pencil-shaped macroconidia (blue square) D2 \& E1 and few tear-shaped micronidia (blue arrows) E2.

Received : June $9^{\text {th }}, 2021$

Accepted : June 19 $9^{\text {th }}, 2021$

Correspondence : Indah Kencana, email: indahkencana@gmail.com 


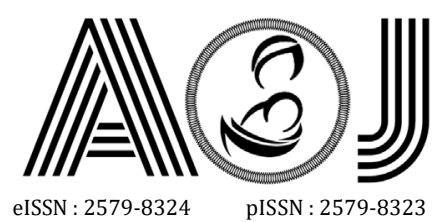

eISSN : 2579-8324
pISSN : 2579-8323

Editorial Room Andalas Obstetrics and Gynecology Journal, $3^{\text {rd }}$ floor of KSM of Obstetrics and Gynecology,

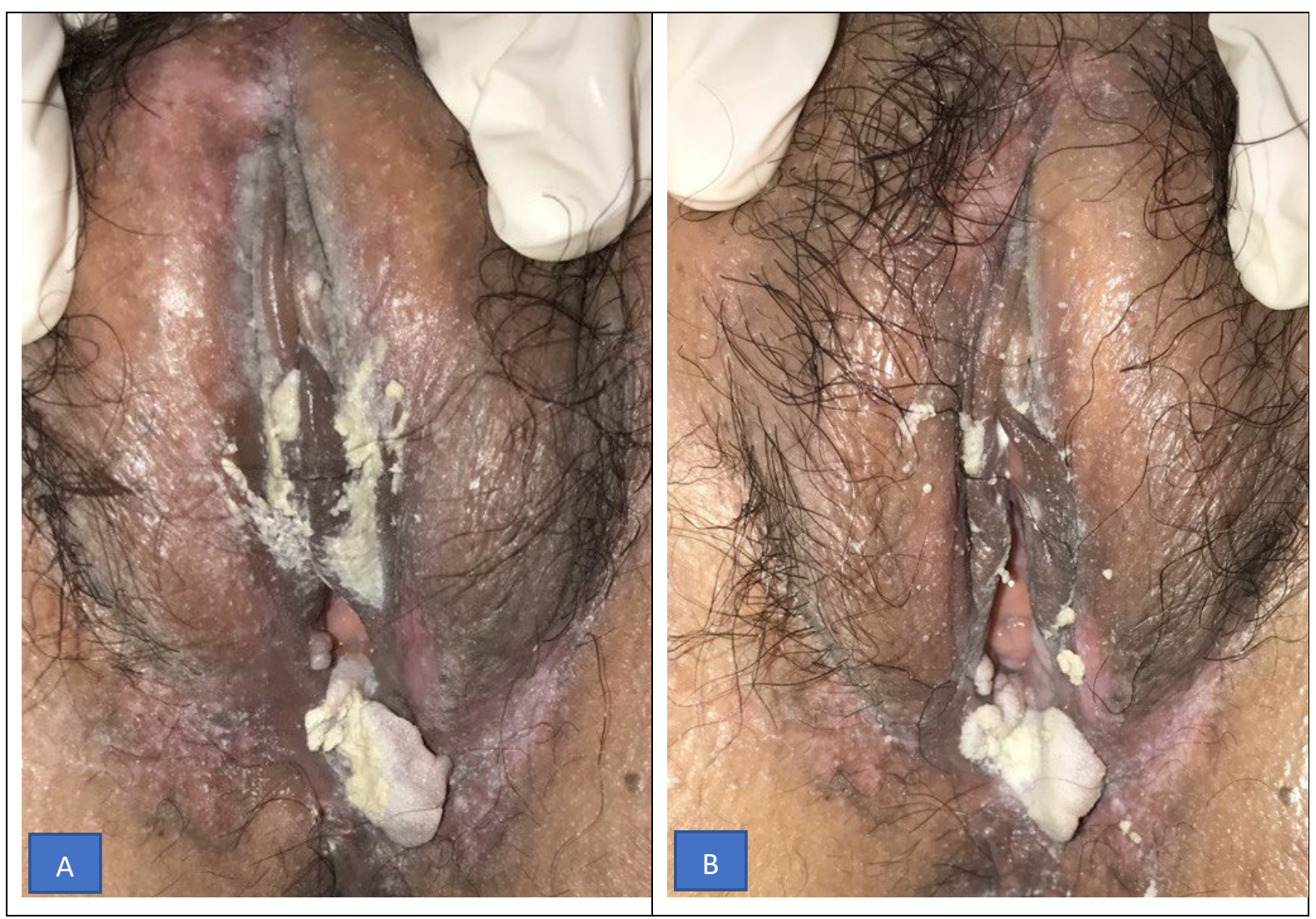

Figure 4. $A$ there is vegetation before acetowhite test and $B$ vegetation after acetowhite test.

Based on anamnesis, physical examination, mycological finding, diagnosis of this patient are Tinea Corporis and Condyloma Acumminata Genital. Treatment of this patient are griseovulfin $900 \mathrm{mg}$, cetirizin tablet $10 \mathrm{mg}$ a day, ketokonazol cream 2\% twice a day, application of Tricholoroacetat $90 \%$ on condyloma acuminata genital.

Received : June $9^{\text {th }}, 2021$ 


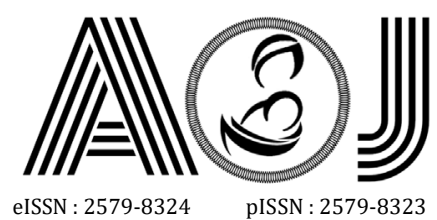

eISSN : 2579-8324
pISSN : 2579-8323

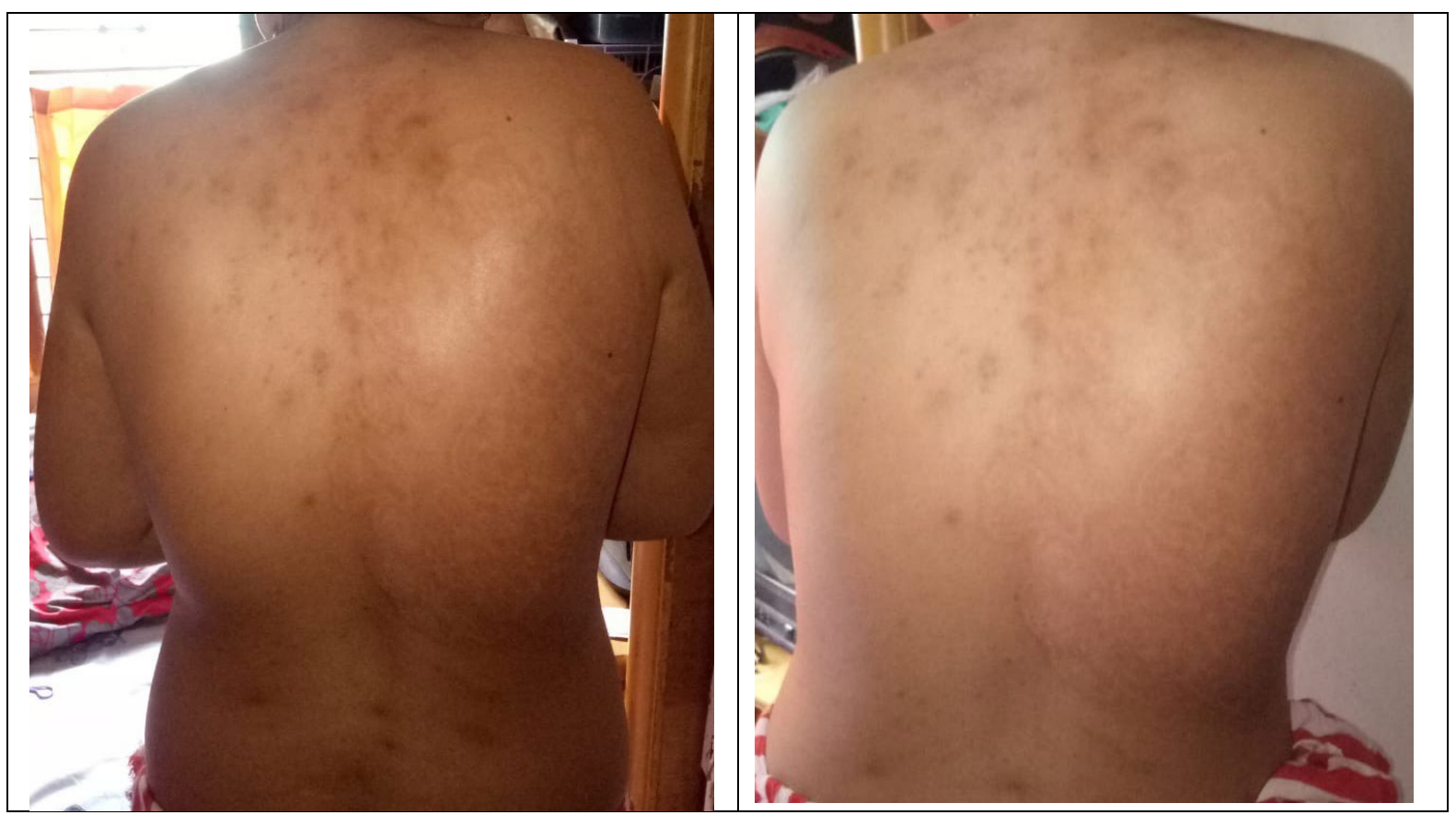

Figure 5. After 2 weeks treatment of tinea corporis.

In HIV, a weakened immune system increases vulnerability to a number of opportunistic infections, cancers, and other conditions. Opportunistic infections (Ols) are defined as infections that are more frequent or more severe because of immune suppression in HIV-infected patients, and they are the major clinical manifestation of HIV patients. OI cause significant morbidity and mortality in people with HIV infection. The risk for the development of OI in HIV patients depends on exposure to potential pathogens, virulence of the pathogens, the degree of host immunity, and the use of antimicrobial prophylaxis. Majority of these OI are associated with an increased hazard of death in HIV patients. Patients experiencing morbidity from opportunistic diseases may have interruptions in antiretroviral therapy (ART) causing more rapid progression of HIV disease. In addition, studies found that Ols cause an up regulation in HIV replication and higher viral load. The introduction of highly active antiretroviral therapy (HAART) has led to a significant reduction in AIDS-related morbidity and mortality. Unfortunately, up to $25 \%$ of all patients discontinue their initial ART regimen because of treatment failure, toxic effects, or noncompliance within the first 8 months of therapy. Since the introduction of ART, a significant decline in Ols and AIDS progression has been observed. ${ }^{1,2,3}$ 


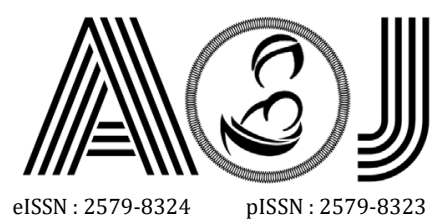

eISSN : 2579-8324
pISSN : 2579-8323

Editorial Room Andalas Obstetrics and Gynecology Journal, $3^{\text {rd }}$ floor of KSM of Obstetrics and Gynecology, RSUP DR. M. Djamil Padang, Jl. Perintis Kemerdekaan Padang, Sumatera Barat 25127

The relative frequencies of specific Ols may vary in different countries and even in different areas within the same country. Knowledge of the most common $\mathrm{Ol}$ of that geographical area will help in implementing the preventive measures against that pathogen. Nevertheless, there is insufficient knowledge about the burden and risk factors for Ols in HIVinfected populations receiving ART in Karnataka, India. ${ }^{1,6,7}$ Patient is a single and never gets married before. Patient had a sexual relation with married male. The last sexual intercourse was 2 years ago, genito-genitally, oro-genitally and ano-genitally. There was no protection (condom) during the sexual intercourse. Patient partner's job is a police. The history of partner sexual intercourse with others was unknown. Patient also never finds out whether the sexual partners have a history of sexually transmitted diseases. Patient partner was died with HIV about 1 year ago. 6 months ago, patient complaint shortness of breathe and admitted in Pulmonology Department with CAP (community acquired pneumonia). Then performed a laboratory examination and obtained an HIV positive. Patient was diagnosed with HIV and regularly taking ARVs drug; Tenolam E once a day.

Tinea corporis is a superficial fungal skin infection of the body caused by dermatophytes. Tinea corporis is present worldwide. It is defined explicitly by the location of the lesions that may involve the trunk, neck, arms, and legs. The incidence of dermatophytosis in HIV patients was about $15-40 \%{ }^{1,2,3,4,5}$

Another vulnerable population includes patients with compromised immune systems. Dermatophytes are a group of pathogenic fungi that cause mostly superficial diseases, further it is more difficult to diagnose dermatophytosis in immunocompromised patients, as clinical presentation is often atypical, in the present case multiples localization were recorded. Dermatophytes are the most prevalent agents of superficial fungal infections. The dermatophyte's ability to attach to the keratinized tissue of skin forms the basis for the dermatophytoses (superficial fungal skin infections. The dermatophytes causing tinea corporis belong to genera Trichophyton, Epidermophyton, and Microsporum. Trichophyton rubrum is the most common species to cause dermatophyte infections in the last 70 years. $T$. Rubrum accounts for 80 to $90 \%$ of the strains. Other common isolates include Trichophyton mentagrophytes and Microsporum audouinii. HIV-positive patients is most commonly 


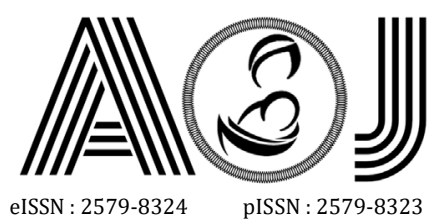

eISSN : 2579-8324
pISSN : 2579-8323

Editorial Room Andalas Obstetrics and Gynecology Journal, $3^{\text {rd }}$ floor of KSM of Obstetrics and Gynecology, RSUP DR. M. Djamil Padang, Jl. Perintis Kemerdekaan Padang, Sumatera Barat 25127

Website:

http://jurnalobgin.fk.unand.ac.id/index.php/JOE

associated with T. rubrum, which is also the most common agent in skin fungal infections. $4,5,6,7$

The diagnosis of tinea corporis is usually clinically based on a thorough history and physical examination. However, testing can be done to confirm the diagnosis. Skin scrapings examined under a microscope with a potassium hydroxide $(\mathrm{KOH})$ preparation will reveal septate and branching long narrow hyphae. However, up to $15 \%$ of cases may yield false negatives when only using $\mathrm{KOH}$ preparations for diagnosis. $7,8,9$

Therefore another method for confirmation is a fungal culture. Fungal cultures are possible but take time for definitive identification. Cultures may begin to see growth in about five days but may take up to four weeks in certain species. Therefore at least four weeks are needed to deem a sample as "no growth." The most common isolation medium used for fungal cultures is a Sabourad dextrose agar (1\% glucose, $4 \%$ mycological peptone agar, water). Identification is by examining the morphology, pigmentation, and surface topography of the culture. ${ }^{10,11}$ There were ring-shaped reddish patches with scaly and itchy on the right back since 3 weeks ago. Patients often scratch it especially when sweating and hot weather. The itchy reddish patches with scaly were increased in number and size on the right back then spreading over the edge to form ring-like patches. Patient complained ring-shaped reddish patches getting more red, scaly, itchy, and wider. Dermatologic state in right back with efflorescence is plaque erythema with annular concentric ring forms, scale, and blackish crust. $\mathrm{KOH} 10 \%$ of skin scrapping show fungal element and fungal culture result is tricophyton rubrum. Patient was diagnosed tinea corporis (TC).

Clinical manifestations of dermatophytosis associated with CD4 cell count of HIV patients in the study showed there are 3 in patients cases of tinea corporis with low CD4 counts $\left(<200\right.$ cells $\left./ \mathrm{mm}^{3}\right)$ and 1 case of tinea cruris with CD4 count of $200-350$ cells $/ \mathrm{mm}^{3}$. Skin disorders such as seborrheic dermatitis, candidiasis cutis and dermatophytosis are common in patients with a CD4 count of 400 cells / mm3. Dermatophyte fungi cases was more found in patient with CD4 count $<200$ cells $/ \mathrm{mm} 3$. This shows that a decrease in the patient's immunological status has an effect on the increased likelihood of dermatophyte fungal 


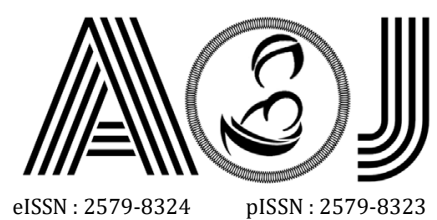

eISSN : 2579-8324
pISSN : 2579-8323

infection, so that more clinical manifestations are found at low CD4 counts. Patient's CD4 in this case less than 200 cells/mm3 which increasing of fungal opportunistic infection.

Oral systemic antifungal drugs effectively eradicate tinea corporis in immunocompromised hosts. Such agents include griseofulvin, ketoconazole, terbinafine, itraconazole, and fluconazole. Dermatophytosis in immunocompromised hosts is more varied and often more severe than in immunocompetent hosts. Early diagnosis and treatment with systemic therapy are important in human immunodeficiency virus (HIV) patients in order to prevent severe infection. ${ }^{7,8,11}$

Erythema gyratum repens is a paraneoplastic figurate erythema typically associated with breast, lung, and esophageal cancer that presents within 1 year of a cancer diagnosis. Tinea pseudoimbricata and erythema gyratum repens can have similar morphology, with pruritic, annular, erythematous plaques composed of concentric rings with a woodgrain appearance and fine scale. Although histopathology is nonspecific, there are no fungal elements as observed in tinea pseudoimbricata. Erythema gyratum repens expands more rapidly than tinea pseudoimbricata and does not worsen with steroids. Superficial erythema annulare centrifugum is a figurate erythema characterized by erythematous annular expanding plaques with trailing scale, not concentric rings. It is associated with dermatophyte infections, drugs, and malignancies. Histopathology is nonspecific, but tight "coat sleeving" of lymphocytes around superficial vessels is suggestive. Tinea pseudoimbricata is a dermatophytosis with the same clinical appearance of multiple concentric rings as tinea imbricata. Unlike tinea imbricata, which is caused by Trichophyton concentricum, tinea pseudoimbricata is caused by $\mathrm{T}$ tonsurans and other dermatophytes. Tinea pseudoimbricata is thought to be a form of tinea incognito associated with longterm topical steroid use. Histopathology is usually nonspecific but may show hyphae in the stratum corneum. Tinea imbricata is an uncommon, superficial mycosis caused by the anthropophilic dermatophyte Trichophyton concentricum. The geographic distribution of this fungus is limited to some islands of Oceania (Melanesia and Polynesia) and, to a lesser extent, to several regions of Southeast Asia (India, Vietnam) and Central or South America (Mexico, Brazil). Typical 


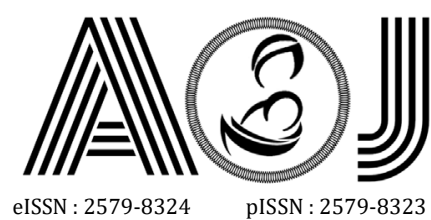

eISSN : 2579-8324
pISSN : 2579-8323

cutaneous lesions present as scaly and polycyclic rings that can extend to form polycyclic plaques, with a lamellar detachment of the scales. ${ }^{1,2,12,14}$

In this case, patient was diagnosed with condyloma cuminata genital based on anamneses, physical examination, and acetowhite test. Anogenital warts are the most common manifestation of genital HPV infection. Estimates show that among patients who contact HPV, only $10 \%$ develop genital warts, with HIV being the most significant predisposing risk factor. Patient with HIV and lower CD4 T count could be increasing risk of infection. 10,11,13,14 CA genital are prevalent in groups at high risk for HIV acquisition and in HIV-infected individuals. In seronegative men who have sex with men, the prevalence of low-risk HPV infection associated with CA genital is about $20 \%$. A recent meta-analysis showed that the prevalence of CA genital in HIV-uninfected populations at high risk for HIV acquisition in subSaharan Africa (such as female sex workers and men and women attending sexually transmitted disease (STD) clinics) ranges from $2.4 \%$ to $14 \%$. HIV-infected men and women have a higher prevalence of HPV infection, CA genital, and premalignant and malignant lesions, compared with age-matched uninfected controls. ${ }^{16,17,18}$

A number of recent studies have shown an increased risk of HIV acquisition in individuals with HPV infection and those with CA genital, and it has been speculated that HPV may enhance HIV acquisition because of inflammation and an increased numbers of HIV target cells at the infection site. HPV clearance, rather than HPV infection, has also been implicated as a factor in HIV acquisition. CA genital could also be a site of enhanced HIV shedding and transmission from HIV-infected individuals to uninfected partners; however, studies to date have not associated HPV infection or CA genital with HIV transmission. ${ }^{17,18,20}$ 6 months ago, there was a lump that sometime felt itchy in below part of vulva. Patient also suffered HIV and got ARV since 6 month ago. Venereologycal state show vegetation in vulva with size $0,2-1,5 \times 1 \times 0,5 \mathrm{~cm}$ with verrucous surface. Acetowhite test is positive result. Patient was diagnosed condyloma acuminata (CA) genital that treated by Tricholoroacetat $90 \%$. The results of lesion do not show significant improvement because patient only got 2 times of treatment. 


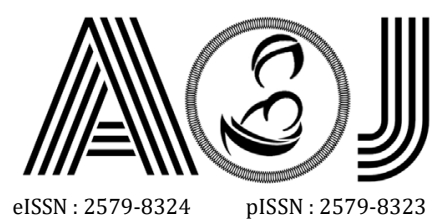

eISSN : 2579-8324
pISSN : 2579-8323

Oral antifungal agents are the drugs of choice for the treatment of tinea corporis in HIV patient. In a comparative study on the efficacy of oral terbinafine, griseofulvin, fluconazole, and itraconazole after 4 weeks of therapy, significant remission was achieved in the terbinafine group and the griseofulvin group. The fluconazole group experienced no significant remission whereas remission was of short duration in the itraconazole group. Currently, oral terbinafine is the drug of choice for the treatment of tinea imbricata. Griseofulvin (not available in many countries, like Canada) can also be effective but may require longer courses of treatment. Commonly used topical antifungal agents include butenafine, ciclopirox, econazole, ketoconazole, miconazole, naftifine, terbinafine, and tolnaftate..$^{1,2,3,10,11,19}$ We treat this patient with griseovulfin $900 \mathrm{mg}$, cetirizin tablet $1 \times 10 \mathrm{mg}$, ketokonazol cream 2\% twice a day, Application of Tricholoroacetat $90 \%$ on condyloma acuminata. After 4 weeks treatment, show improvement with hypopigmentation and hyperpigmentation macules on back.

\section{CONCLUSION}

A case of clinical appearance of tinea corporis resembles with tinea imbricata and condyloma acuminate genital with HIV in 33 years-old women. The diagnosis was based on anamnesis, physical examinations, mycological findings, and acetowhite test. After 4 weeks treatment, tinea corporis show improvement with hypopigmentation and hyperpigmentation macules on back, however CA size lesion no reduced.

\section{REFERENCES}

1. Panel on Opportunistic Infections in HIV-Infected Adults and Adolescents. Guidelines for the prevention and treatment of opportunistic infections in HIV-infected adults and adolescents: recommendations from the Centers for Disease Control and Prevention, the National Institutes of Health, and the HIV Medicine Association of the Infectious Diseases Society of America. 2013.

2. Buchacz $K$, Lau $B$, Jing $Y$, et al. Incidence of AIDS-defining opportunistic infections in a multicohort analysis of hiv-infected persons in the United States and Canada, 20002010. J Infect Dis 2016; 214: 862-72. 


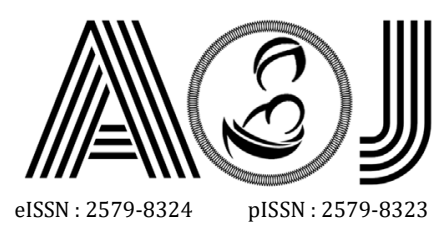

Editorial Room Andalas Obstetrics and Gynecology Journal, $3^{\text {rd }}$ floor of KSM of Obstetrics and Gynecology, RSUP DR. M. Djamil Padang, Jl. Perintis Kemerdekaan Padang, Sumatera Barat 25127

3. Aly R, Berger T. Common superficial fungal infections in patients with AIDS. Clin Infect Dis 1996; 22 (Suppl. 2): S128-S132.

4. Elmets CA. Management of common superficial fungal infections in patients with AIDS. J Am Acad Dermatol 1994; 31: S60-S63.

5. Dahl MV. Dermatophytosis and the immune response. J Am Acad Dermatol 1994; 31: S34-S41.

6. Wagner DK, Sohnle PG. Cutaneous defenses against dermatophytes and yeasts. Clin Microbiol Rev 1995; 8: 317-355. 7 McGregor JM, Hay RJ. An immunoinhibitory cell wall glycoprotein (mannan) from Trichophyton rubrum. J Invest Dermatol 1991; 97: 955-956. 8 Hay RJ, Moore M. Mycology. In: Champion RH, Burton JL, Burns DA, Breathnach SM, eds. Textbook of Dermatology, 6th edn. London: Blackwell Science, 2001.

7. Chastain MA, Reed RJ, Pankey GA. Deep dermatophytosis: report of two cases and review of the literature. Cutis 2001; 67: 457-462. 10 Tsang P, Hopkins T, JimenezLucho V. Deep dermatophytosis caused by Trichophyton rubrum in a patient with AIDS. J Am Acad Dermatol 1996; 34: 1090-1091.

8. Johnson RA. An update on dermatophytosis: dermatophyte infections in human immune deficiency virus (HIV) disease. J Am Acad Dermatol 2000; 43: S135-S142.

9. Lobrone JP, Lazare K, Medard FT, Zekeng L. Clinical and biological study of superficial mycoses in AIDS patients in Yaounde. Program and Abstracts of the 12th International Conference on AIDS, Geneva. Geneva: World Health Organization, 1998: Abstract 31218.

10. Banura C, Mirembe FM, Orem J, Mbonye AK, Kasasa S, Mbidde EK. Prevalence, incidence and risk factors for anogenital warts in Sub Saharan Africa: a systematic review and meta analysis. Infect Agent Cancer 2013; 8:27. [PMC free article] [PubMed] [Google Scholar]

11. Chin-Hong PV, Palefsky JM. Human papillomavirus anogenital disease in HIV-infected individuals. Dermatol Ther 2005; 18:67-76. [PubMed] [Google Scholar]

12. Houlihan $C F$, Larke NL, Watson-Jones $D$, et al. Human papillomavirus infection and increased risk of HIV acquisition. A systematic review and metaanalysis. AIDS 2012; 26:2211-22. [PMC free article] [PubMed] [Google Scholar]

13. Lissouba $P$, Van de Perre $P$, Auvert B. Association of genital human papillomavirus infection with HIV acquisition: a systematic review and meta-analysis. Sex Transm Infect 2013; 89:350-6. [PMC free article] [PubMed] [Google Scholar]

14. Smith JS, Moses S, Hudgens MG, et al. . Increased risk of HIV acquisition among Kenyan men with human papillomavirus infection. J Infect Dis 2010; 201:1677-85. [PMC free article] [PubMed] [Google Scholar] 


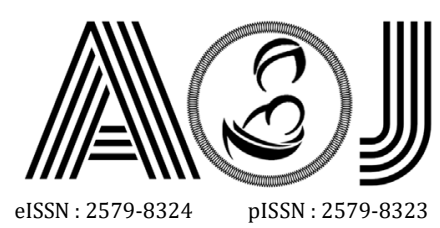

Editorial Room Andalas Obstetrics and Gynecology Journal, $3^{\text {rd }}$ floor of KSM of Obstetrics and Gynecology,

RSUP DR. M. Djamil Padang, Jl. Perintis Kemerdekaan Padang, Sumatera Barat 25127

15. Smith-McCune KK, Shiboski S, Chirenje MZ, et al. . Type-specific cervico-vaginal human papillomavirus infection increases risk of HIV acquisition independent of other sexually transmitted infections. PLoS One 2010; 5:e10094. [PMC free article] [PubMed] [Google Scholar]

16. Bennetts LE, Wagner M, Giuliano AR, Palefsky JM, Steben M, Weiss TW. Associations of Anogenital Low-Risk Human Papillomavirus Infection With Cancer and Acquisition of HIV. Sex Transm Dis 2015; 42:541-4. [PubMed] [Google Scholar]

17. 19. Jin F, Prestage GP, Imrie J, et al. . Anal sexually transmitted infections and risk of HIV infection in homosexual men.J Acquir Immune Defic Syndr 2010; 53:144-9. [PubMed] [Google Scholar]

18. Averbach SH, Gravitt PE, Nowak RG, et al. . The association between cervical human papillomavirus infection and HIV acquisition among women in Zimbabwe. AIDS 2010; 24:1035-42. [PMC free article] [PubMed] [Google Scholar]

19. Tobian AA, Grabowski MK, Kigozi G, et al. . Human papillomavirus clearance among males is associated with HIV acquisition and increased dendritic cell density in the foreskin.J Infect Dis 2013; 207:1713-22. [PMC free article] [PubMed] [Google Scholar]

20. Nenoff P, Overbeck C, Uhrlaß S, Krüger C, Gräser Y. Tinea corporis durch den seltenen geophilen Dermatophyten Microsporum praecox [Tinea corporis due to the rare geophilic dermatophyte Microsporum praecox]. Hautarzt. 2017 May;68(5):396-402. German. doi: 10.1007/s00105-016-3867-2. PMID: 27586990. 